\title{
The Relationship Between Dengue Virus and The Existence of Allah Through al-Dilalah al-Aqliyyah Based on Maqasid al-Tasdiq
}

Ahmad Hafiz Ali Makdom, Mohd Hasrul Shuhari, Mohammed Muneer'deen Olodo Al-Shafi'i, Wan Hishamudin Wan Jusoh

To Link this Article: http://dx.doi.org/10.6007/IJARBSS/v11-i2/8660

DOI:10.6007/IJARBSS/v11-i2/8660

Received: 05 December 2020, Revised: 08 January 2021, Accepted: 24 January 2021

Published Online: 12 February 2021

In-Text Citation: (Makdom et al., 2021)

To Cite this Article: Makdom, A. H. A., Shuhari, M. H., Al-Shafi'i, M. M. O., \& Jusoh, W. H. W. (2021). The Relationship Between Dengue Virus and The Existence of Allah Through al-Dilalah al-Aqliyyah Based on Maqasid al-Tasdiq. International Journal of Academic Research in Business and Social Sciences, 11(2), 177185.

Copyright: (c) 2021 The Author(s)

Published by Human Resource Management Academic Research Society (www.hrmars.com)

This article is published under the Creative Commons Attribution (CC BY 4.0) license. Anyone may reproduce, distribute, translate and create derivative works of this article (for both commercial and non-commercial purposes), subject to full attribution to the original publication and authors. The full terms of this license may be seen

at: http://creativecommons.org/licences/by/4.0/legalcode

Vol. 11, No. 2, 2021, Pg. 177 - 185

Full Terms \& Conditions of access and use can be found at http://hrmars.com/index.php/pages/detail/publication-ethics 


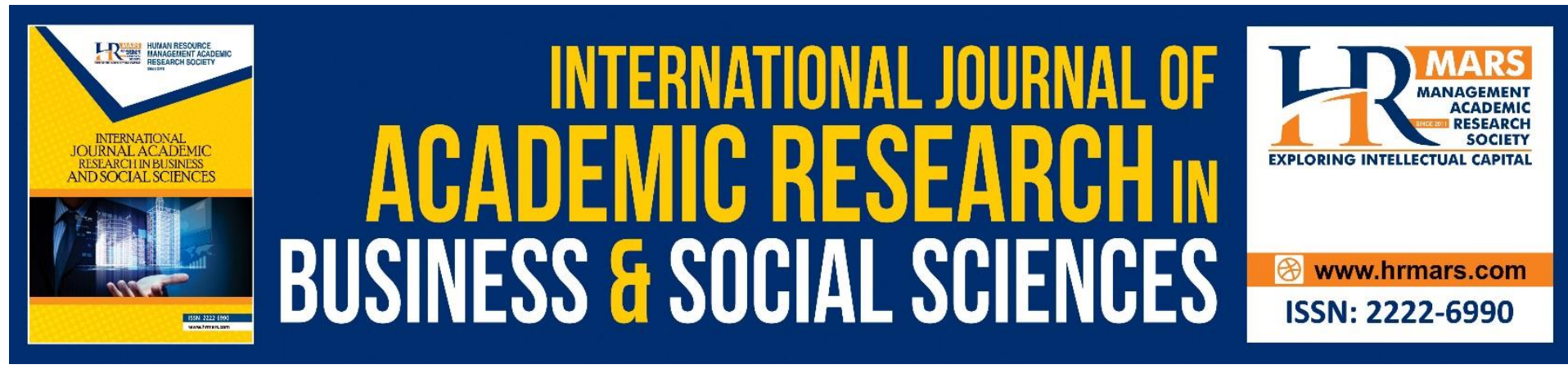

\title{
The Relationship Between Dengue Virus and The Existence of Allah Through al-Dilalah al-'Aqliyyah Based on Maqasid al-Tasdiq
}

\author{
Ahmad Hafiz Ali Makdom, Mohd Hasrul Shuhari, Mohammed \\ Muneer'deen Olodo Al-Shafi'i, Wan Hishamudin Wan Jusoh \\ Faculty of Islamic Contemporary Studies (FKI), University of Sultan Zainal Abidin (UniSZA), \\ Gong Badak Campus, 21300 Kuala Nerus, Terengganu, Malaysia \\ Email: hasrulshuhari@unisza.edu.my
}

\begin{abstract}
Dengue is an animal virus carried by Aedes mosquitoes. The dengue virus is a major factor in the spread of various diseases that are dangerous to man. It starts at an early stage through Dengue Fever (DF) and can lead to life threatening sickness called Dengue Fever Syndrome (DHF). Therefore, with this dangerous syndrome one can, or does not understand one can, be more confident in a substance that the Almighty is regulating the disease through His will from the beginning. This is so because we can proof the existence of God through the evidence of ijmali and the beautiful nature. Therefore, the natural phenomenon manifested in dengue virus can further strengthen the hold in the heart of man, proven through maqasid al-tasdiq in the form of qiyas. This qualitative study applies the method of documentation and data analysis in describing the causes and chronology of dengue virus, especially in Malaysia, and establishes discussions regarding al-dilalah al-'aqliyyah, which shows we can use common sense to understand natural phenomena. This paper then relates dengue virus affliction to the proposition that there is one Almighty substance, God, who rules the universe. As a result, the infection of dengue virus, causing man to get Dengue Fever (DF) and Dengue Fever Syndrome (DHF), strengthens one's understanding and belief in the existence of Allah in regulating all-natural phenomena.
\end{abstract}

Keywords: Dengue Virus, Existence of Allah, al-Dilalah al-'Aqliyyah, Maqasid al-Tasdiq, Qiyas.

\section{Introduction}

Dengue fever is a dangerous threat to man, especially in Malaysia. This is due to Dengue virus (DENV), a type of virus that spreads through mosquitoes (Er \& Abdullah, 2016). It is a vectorborne disease that is a major threat to general public health in Malaysia. In addition, dengue fever is a major factor responsible for the very high health statistics in Malaysia, and in most other countries with tropical climate (Rasidi et al., 2013; Seng et al., 2005).

In addition, dengue fever spreads mostly through female Aedes mosquitoes because they carry a specifically dangerous virus. This virus spreads through female Aedes mosquito bites because female Aedes mosquitoes get desperately in need of blood to lay eggs while the diet of male Aedes mosquitoes consists of plant-based fluids. As a result, it is clear that 
dengue fever is caused by female Aedes mosquito bites (Sulaiman et al., 2016; Rahman, 1988).

And because of the spread of the dengue epidemic in Malaysia, people have realized that there is one Almighty substance that has regulated all epidemics based on His wishes, including this dengue virus epidemic. This makes man turn to God and strengthens the heart through al-dilālah al-'aqliyyah on the existence, oneness of Allah and His power and will without being hindered by anyone. This happens because one who believes in Allah must believe in the qada' and qadar of Allah that has been set from the very beginning of existence (Ba'atiyyah, 2008). This is a particularly strong argument in showing the existence of God who is in control of everything.

\section{Virus and Dengue Fever Chronology}

Dengue Fever (DF) and Dengue Fever Syndrome (DHF) spread through flavivirus infections. The carriers of the virus, especially in Asian and Japanese countries, consist of Aedes aegypti and Aedes albopictus that spread the disease to humans through their infectious bites (Pang et al., 1991). Both types of mosquitoes are small, black and have white stripes on their limbs (Shafie, 2008). In contrast, Aedes polynensis and Aedes pseudoscutellaris are vectors of Dengue Fever (DF) around the Pacific Islands (Vaughn et al., 1997).

Aedes aegypti is a mosquito specie that relies on a large number of people for its existence (Shafie, 2008). It lives in countries with temperatures around 10 degrees Celsius and not usually found in areas that are more than 1000 meters above sea level (Haines et al., 2006), agricultural areas and so on. Mosquito bites happen around dusk and dawn (Halstead, 2007; Rudnick, 1984; Gubler et al., 2001). And, there are views that the time mosquitoes bite is around early morning and late afternoon (Su, 2008).

The area located at an altitude of $\mathbf{2 1 2 1}$ meters above sea level in India and $\mathbf{2 2 0 0}$ meters in Colombia above sea level is where most Aedes mosquitoes come from. This Aedes aegypti mosquito likes to live around humans, especially in dark, hidden and humid places such as bedrooms and so on (Kurane et al., 2001).

Ismail (2005), states that the life cycle of Aedes mosquitoes undergoes four phases. The first stage is the phase of becoming an egg. The outer wall of the Aedes mosquito egg is black and small, about 50 microns, and even looks round and oval. The eggs appear to be in the shape of a spider's web when viewed and studied through a microscope (Reiter et al., 2003). Aedes mosquitoes can lay 60-90 eggs in each spawning phase. Thirty days is the life span of female mosquitoes, and they can lay eggs up to 10 times. In addition, to achieve perfect maturity, it takes about 24 to 27 hours. At this stage, the eggs can withstand the climate and dry weather and can even live for a long time. If the water level rises and the egg is flooded with water then it will release the larvae after hatching in this first stage (Halsted, 2007; Gubler, 2004 \& MOH, 2013).

The second phase is larvae, after the eggs have hatched. There are four phases in the process of larvae maturation. Consecutive peeling of the skin occurs three times, stages I, II, III, and IV. With the help of his mouth brush, it moves and eats all the micro-organisms as well as organic ingredients (Reiter, 2003).

Next is the pupa stage, a curved-like shape. Pupa has the power to move anywhere even though it does not need food. Drastic changes occur to pupa when it transforms into a mosquito and lives in the air. Pupa takes two days when it is in the tropics. In the cephalothorax there is a rupture on pupa skin when it is on the surface of the water. Then, 
the adult mosquito emerges and from its cocoon shell releases its legs and wings (Reiter, 2003).

The transition of dengue virus occurs when mosquitoes suck human blood through bites in the body so that the mosquitoes have a very high dengue virus. Mosquito bite is a major route to spread dengue virus among humans in general. The body of the mosquito will multiply on the part of the mosquito's salivary glands when human blood is sucked by the female mosquito. The breeding process takes about five to eight days and even the virus of the disease can spread directly when the dengue patient whose blood is sucked by the mosquito is disturbed and the mosquito quickly sucks the blood of others (Shafie, 2008).

The debate regarding the origin of dengue virus is still ongoing. Most researchers are of the opinion that the development of trade and shipping industry in Europe, Asia and Africa in the $18^{\text {th }}$ century was a cause of the spread of dengue virus. The water storage containers found in the ship are used as habitat for the breeding of Aedes aegypti mosquitoes. Although the voyage of a ship takes a long time, but the mosquito still manages to strengthen its transmission cycle (Shafie, 2008).

Dengue Fever Disease (DHF) first appeared in the Philippines in 1953, and it spread to children between ages four and six. Asia and South America are among the places with the highest record of Dengue Fever (DF), with very high numbers, after the World War II. It is opined that geographical, climatic, demographic and social factors are the bases for the spread of Dengue Fever (Shafie, 2008).

The sharp increase in Dengue Fever (DF) is mainly due to the process of urbanization. Clean water supply, housing, health care, congestion and squatters are problems that arise when the process of excessive urbanization to an uncontrollable level occurs, as it leads to Dengue Fever (DF) case soaring (Shafie, 2008). The advanced modern transportation system is also one of the reasons that contribute towards the increase in cases of these diseases. This is especially true of land and air transport due to the rapid spread of the dengue virus through humans to other places and countries. Not only that, but cases involving dengue virus have also increased due to infrastructure factors, health facilities and community education (Shafie, 2008).

\section{Al-Dilalah Al-'Aqliyyah}

One's understanding and knowledge is not just blind taqlid, but also through other means or propositions even if the matter is trivial. A person's understanding of something is referred to as al-dilalah, and it is divided into several parts (Al-Bajuri, 2005). Al-Dilalah is to understand something from something else. This is how one understands matter from the word 'sky'. The word 'sky' is called as dal or dalīl (indicator) and the matter is called madlul (indicated) (AlDamanhuri, 2015).

Al-Dilalah is divided into two parts, namely al-Dilalah al-lafziyyah (oral evidence) and al-Dilalah ghayr al-lafz̧iyyah (non-oral, verbal). Al-Dilalah al-lafziyyah is something that can be understood through the voice of something whether from human beings or animals. While al-Dilalah ghayr al-lafziyyah is the understanding of something from sources other than voice (al-Ibrahimi, 1937). And each of the two parts is divided into three parts, namely al-Dilalah altabi iyyah (natural), al-Dilalah al-'aqliyyah (logical) and al-Dilalah al-wad'iyyah (conceptual) (al-Sa'di, 2011).

Al-Dilalah al-lafziyyah al-tabiiyyah is an understanding of the voice in nature. If something happens to a person then such a person would produce a voice basically. For example, when someone says 'ouch' to show that he is in pain, and when someone says 'wow' 
to show amazement. Al-Dilalah al-lafziyyah al-'aqliyyah is different from al-țabi'iyyah because it can be understood in accordance with what is acceptable through common sense. For example, when we hear a human voice in the house it shows someone is in the house. And, al-Dilalah al-lafziyyah al-wad'iyyah is the understanding of a voice or words that have been accustomed to among people. For example, when a person mentions al-fil in Arabic then it can be understood from him that what is meant is an elephant. Similarly, when a person mentions a book then it can be understood from him that it consists of sheets of paper, outer cover, writing and so on which are commonly known. Therefore, al-Dilalah which is meant in logic, the majority refers to al-Dilalah al-lafziyyah based on al-wad'iyyah. This is so because the concept is divided into three, namely al-Dilalah al-Mutabaqah (appropriate), al-Dilalah alTadammuniyyah (descriptive) and al-Dilalah al-Iltizamiyyah (inscriptive) (Hijazi, 2016: 42-43, al-Ibrahimi, 1937: 11).

Al-Dilalah ghayr al-lafziyyah in 'aqliyyah (logical) is to understand something against what can be accepted by a healthy mind, such as understanding that change in something shows the thing is new. The change of something is mentioned as a proposition and the new one is madlul (indicated). As for al-Dilalah al-Tabi iyyah, it is to understand something from the natural habit such as understanding that yellowish face shows a person is afraid. So, the yellowish face is an indicator while fear is the indicated. Al-Dilalah ghayr al-Lafziyyah alWad'iyyah on the other hand is to be able to understand something that has been agreed upon together such as understanding the gesture with the hand shows the meaning of 'yes' or 'no' (Al-Urmi, 2015; Hijazi, 2016; al-Ibrahimi, 1937).

Therefore, to be convinced of the existence of God, it is enough to study the universe naturally through its day and night occurrences. Things change and move from place to place and from time to time, and one's testimony of this world is a proof to know its madlul, the Creator. For Muslims, the creator is Allah swt. Looking at the beautiful colourful world makes one know there is a governing power, different from the creature, that is governing this world, even though one does not acknowledge Allah swt as one's God.

According to al-Damanhuri (2011), al-Razi's view states that al-Tasdiq has four tasawwur. This is because, something is said to be al-Tasdiq when the four Tasawwur are achieved. The four tasawwur are: the existence of al-tasawwur for al-mawdu', al-tasawwur for al-Mahmul, the ratio between al-mawdu' and al-Mahmul and the occurrence of the law of relevance and attribution to it.

Among the examples involved between al-mawdu' and al-Mahmul is that Zaid was a standing man. So if you want to make the verse as al-tasdiq, one must first explain the substance Zaid, and then the person who stands, explain the relationship and proposition between Zaid and a person who stands and announce the law of proposition between Zaid and a person who stands. According to al-Razi, the legal condition to be mentioned as alTasdiq should have these four tasawwur. However, most scholars state that the legal condition to be called as al-tasdiq is only to have the fourth al-tașawwur, which is tasawwur, the law of attribution between al-mawdu' and al-Mahmul does not require the first to third tasawwur, tasawwur against mawdu', tasawwur against mahmul and tasawwur against between al-mawdu' and al-Mahmul. This is so because according to scholars if one sets out the verses that contain the elements al-mawdu' and al-Mahmul, then indirectly he has three forms of al-tasawwur that were discussed earlier. From this majority opinion it is easier to confirm something as al-tasdiq base on the result of the fourth tasawwur only as already stated. 


\section{The Concept of Al-Tasdiq through Al-Qiyas to Proof the Existence of God, the Creator}

As clearly stated above, if discussed logically, the term 'knowledge' will change either alTasawwur or al-Tasdiq. Al-Quwaysini (2014) maintains that the science according to the logical scholars is also known as al-Tasdiq. Al-Tasdiq is an observation and knowledge of the occurrence of the law of consecration between al-mawdu' and al-Mahmul refers to a positive statement and the absence of the law of consecration refers to the opposite statement. This is so because knowledge is merely to know if it is closely related to a matter in the form of alMufrad like a human then it is named as al-Tasawwur. On the other hand, if one simply knows that it is closely related to the occurrence of the law of intercession by al-Murakkab that is, a matter is arranged more than one or the occurrence of the intercession is not then it is called al-Tasdiq. If viewed more specifically, the opinion put forward by al-Quwaysini (2014) is synonymous with the views put forward by al-Damanhuri (2011) and other jurists. When one mentions with respect to scholars then it refers to a philosopher.

Based on the view of al-Quwaysini that there is a statement against al-Mahmul and alMawdu' which refers to the positive, and there are also references to the negative as the verse of Muhammad is an understanding person. So, judging by someone on the understanding of Muhammad is called al-Tasdiq which is positive which is true as it is convicted in the verse. On the other hand, if it is determined that Muhammad is an ignorant person then it is a negative al-Tasdiq that is not even in line with the verse of Muhammad is an understanding person. According to Hijazi (2016), the knowledge of the law of attribution between al-Mawdu' and al-Mahmul should go through two paths, namely either by way of belief or by way of conjecture. Therefore, the law of conviction for the occurrence of such annexation not only covers the level of confidence but even with a strong path of suspicion has been calculated to say the matter as al-Tasdiq. Therefore, al-Damanhuri (2016) states that the proof of belief whether the existence of god and so on is applied by scholars through alqiyas as a detailed proposition and remove the doubts that exist in the heart. Logic scholars refer to this method of qiyas as maqasid al-Tasdiq.

Al-Qiyas is a matter that is very important to the mutakallimin in the selection of faith to achieve the real and concrete goal that is a strong belief in Allah swt and others such as the prophets and apostles. Not only that, al-qiyas is also known as dalil or burhan (al-Quwaysini, 2014). Therefore, in this istidlal knowledge of monotheism must be based on a strong element of belief rather than suspicion and ignorance (al-Sharqawi, 2013).

If a person adheres to a superstitious belief, his faith is not regarded as he falls disbelief and disobedience to God (al-Sharqawi, 2013, al-Tilimsani, 2009). As a result, a person will be confident in relation to the belief in divinity, prophethood and al-Sam iyyat in a state of having a clear proposition and not even the opposite, which is just blind taqlid without belief. This is because the position of taqlid in the matter of faith is not at all recognized and commanded by mutakallimun Ahl al-Sunnah wa al-Jama'ah, there is even a dispute between scholars on whether the status of a person who engages in taqlid is referred as a Muslim and believer or vice versa ( al-Dusuqi, 2012).

Linguistically, al-Qiyas is to measure a thing on an example of something else (alDamanhuri, 2011). It is formed through several qadiyyah (premise) and when the qadiyah is accurate and correct, then must be able to receive the correct result (al-Abhari, 2003). Alqiyas is basically divided into two, namely al-basit and al-murakkab. Al-Qiyas al-basiț is a qiyas built by the majority of mutakallimin in arguing on every attribute of Allah whether it is obligatory on the mind or impossible on him. This is so because al-qiyas in the form of al-basit is easy because it only requires two premises to produce the true result. On the other hand, 
al-qiyas al-Murakkab is rare and used by the scholars of faith. It is built on more than two premises to produce a result that is accurate and acceptable (al-Damanhuri, 2011).

\section{Dengue Virus Diseases Strengthen Mind Understanding God's Existence}

When there is a dangerous disease called Dengue Fever caused by Aedes mosquito, then we must be convinced that the disease has been determined by God, from the beginning, through His iradah tanjizi qadim. In fact, the incident will happen as He wills by ta'alluq qudrah Allah to this dengue virus as ta'alluq tanjizi hadith. If the occurrence of the dengue virus that results in the occurrence of a person with Dengue Fever without being in line with the will of God at all, then it shows a weakness in the substance of God and even that thing is impossible to happen to God. This is so because all possible things like the dengue virus must be in line with the ta'alluq qudrah of Allah with what He has determined based on His ta'alluq iradah since the beginning. Similarly, the qudrah and iradah of Allah must be in line with the nature of His knowledge. If it contradicts His knowledge of what God wants and holds then it shows weakness in the essence of God. Therefore, this weakness that happens to God is impossible for the common sense to accept. In addition, a person must be satisfied with what Allah swt has determined through His qada and qadar from the beginning.

In addition, in terms of kasb (effort) and ikhtiyar, human beings should work hard to prevent themselves and their families from getting caught in Dengue Fever, by cleaning the areas that become Aedes mosquito focus and other preventive practices. That is the true foundation according to Ahl al-Sunnah wa al-Jama'ah. It is not like the Jabariyyah who will surrender everything to God without making the slightest effort because they do not recognize the existence of deeds and efforts on the slaves. Nor can it be like the Qadariyyah and Mu'tazilah who try hard to avoid themselves from the dengue virus but do not leave the matter at the same time to Allah because they believe this dengue virus will be destroyed because of their efforts alone without being associated with God.

With this solid and true understanding, a person becomes stronger in his belief in the existence of God in organizing and governing everything. This is so because al-Dilalah al'aqliyyah leads to the existence of God. And this makes al-Dilalah al-'aqliyyah towards his divine beliefs more stable and stronger.

\section{Conclusion}

Dengue virus is one of the causes of life-threatening diseases, especially in Malaysia, through Dengue Fever. The cause is from the mosquito bites of Aedes albopictus and Aedes aegypti when contained in its small body found in Asian countries. Not only that, but the process of the occurrence of Aedes mosquitoes from the egg stage to become a mosquito contributes and strengthens one's confidence in the existence of Almighty God. The belief gained as a result of this chronology makes al-Dilalah al-'aqliyyah or one's understanding through the intellect of the concept of divinity more and more obvious and not just a blind belief. Therefore, Ahl al-Sunnah wa al-Jama'ah emphasize the argument of tafsili through the application of al-qiyas to achieve a high level of confidence in the heart's hold regarding the substance of God and all His perfect attributes. With this, the weak argument that this world can be strengthened is not just an argument that unravels the ambiguity of the scholars of faith but also the natural phenomena in the form of Dengue virus also makes man unable to reason on the existence of Allah. 


\section{Corresponding Author}

Mohd Hasrul Shuhari

Centre for Usuluddin Studies, Faculty of Islamic Contemporary Studies (FKI), University of Sultan Zainal Abidin (UniSZA), Gong Badak Campus, 21300 Kuala Nerus, Terengganu, Malaysia.

Email: hasrulshuhari@unisza.edu.my

\section{References}

Rahman, A. W. A. (1988). Antropod Sebagai Vektor Penyakit, Malaysia: Dewan Bahasa Pustaka.

Al-Abhari, A. D. (2018). Mughni al-Tullab Sharh Matn Isaghuji, Syria: Dar al-Fayha'.

Ali-Ba'atiyyah, M. D. (2008). Ghayah al-Muna Sharh Safinah al-Naja, Tarim: Maktabah Tarim al-Hadithiyyah.

Al-Bajuri, I. M. (2005). Hashiyah al-Bajuri 'ala Matn al-Sullam, Indonesia: Al-Haramain Jaya Indonesia.

Al-Damanhuri, A. A. M. (2011). Idah al-Mubham Min Ma'aniy al-Sullam Jakarta: Dar al-Kutub al-Islamiyyah.

Al-Damanhuri, A. A. M. (2015). Idah al-Mubham Min Ma'aniy al-Sullam. Egypt: Dar al-Nur alMubin li al-Nashr wa al-Tawzi'.

Al-Dusuqi, M. A. (2012). Hashiyah al-Dusuqi 'ala Sharh Umm al-Barahin, Jakarta: Dar al-Kutub

Al-Islamiyyah. Er A. C. and Abdullah W. (2016). Menangani Wabak Denggi di Malaysia: Satu Tinjauan Kaedah Rawatan dan Pencegahan. Malaysian Journal of Society and Space. Volume. 12, No. 9, pp. 56-68.

Gubler, D. J., Reiter, P., Ebi, K. L., Yap, W., Nasci, R., \& Patz, J. A. (2001). Climate Variability and Change in the United States: Potential Impacts on Vector-and rodent-borne disease. Journal of National Medicine. No. 8, pp. 71-73.

Gubler, D. J. (2004). Cities Spawn Epidemic Dengue Viruses. Journal of National Medicine, No. 10, pp. $129-130$.

Haines, A., Kovats, R. S., Campbell, L. D., Corvalan, C. (2006). Climate Change and Human Health: Impact, Vulnerability and Public Health. Journal of Public Health, Volume 120, No. 7 pp. 585-596.

Halsted, S. B. (2007). “Dengue," The Lancet, No. 374, pp. 1644-1652.

Al-Hijazi, A. J. H. (2016). Al-Mursyid al-Salim fi al-Mantiq al-Hadith wa al-Qadim. Terengganu: Dar 'Umar al-Mukhtar.

Al-Ibrahimi, M. N. (1937). 'Ilm al-Manțiq Li al-Mudarris al-'Arabiyyah Wa al-Ma'ahid alDiniyyah Bi Andunisiya. Egypt: Sharikah Maktabah Wa Matba'ah Mustafa al-Babi alHalabi Wa Awladih Bi Misr.

Ismail, F., Makhtar, M. (2006). Classification of Risk in Dengue Fever and Dengue Hemorrhagic Fever Using Rule Based Expert System. Kuala Lumpur International Conference on Biomedical Engineering. pp. 50-53

Kurane, I., \& Takasaki, T., (2001). Dengue Fever and Dengue Hemorrhagic Fever: Challenges of Controlling an Enemy Still At Large. Reviews in Medical Virology, No. 11, pp. 301-311.

Rasidi, M. N. M., Sahani, M., Othman, H., Hod, R., Idrus S., Ali Z. M., Choy, E. C., \& Rosli, M. H. (2013). Aplikasi Sistem Maklumat Geografi untuk Pemetaan Reruang-masa: Suatu Kajian Kes Denggi di Daerah Seremban, Negeri Sembilan, Malaysia. Sains Malaysiana, Volume 42, No. 8, pp. 1073-1080 
Pang, T., Hasan, H., \& Ramalingam, S. (1991). Demam Denggi dan Demam Denggi Berdarah. Kuala Lumpur : Dewan Bahasa dan Pustaka.

Al-Quwaysini, H. D. (2014). Sharh al-Shaykh Ḥasan Darwish al-Quwaysini 'ala al-Sullam fĩ alManțiq, Jakarta: Dār al-Kutub al-Islāmiyyah.

Reiter, P., Lathrop, S., \& Bunning. (2003). Texas Lifestyle Limits Transmission of Dengue Virus. Emerging Infectious Diseases. No. 9, pp. 86-89.

Rudnick, A. (1984). Ecology of Dengue Virus. Asian Journal of Infections Disease. Volume 2, pp. 156-160.

Al-Sa'dī, A. M. (2011). Al-Sharḥ al-Wāọiḥ li Naẓm al-Sullam al-Murawnaq. Egypt: Dar al-Nur alMubin li al-Nashr wa al-Tawzī‘.

Seng, S. B., Chong, A. K., \& Moore, A. (2005). Geostatistikal Modelling, Analysis and Mapping of Epidemiology of Dengue Fever in Johor State, Malaysia. The $17^{\text {th }}$ Annual Colloqium of the Spatial Information Research Centre, University of Otago, Dunedin, New Zealand. pp. 24-25.

Shafie, A. (2008). Aplikasi Sistem Maklumat Geografi (GIS) Bagi Mengenal Pasti Kawasan Berisiko Tinggi Bagi Penyakit Demam Denggi dan Demam Denggi Berdarah di Georgetown, Pulau Pinang. PhD dissertation, University Science of Malaysia.

Al-Sharqawi, A. H. (2013) Hashiyah al-Sharqawi 'ala al-Hudhudi, Jakarta: Dar al-Kutub al'Islamiyyah.

Su, G. L. (2008). Correlation of Climatic Factors and Dengue Incidence in Metro Manila, Philippines. Ambio. No. 37 pp. 292-294.

Sulaiman, N. S., \& Choy, E. A. (2016). Pengawalan dan Pencegahan Denggi di Malaysia: Satu Tinjauan Terhadap Penglibatan Kerajaan Malaysia. Journal of Social Sciences and Humanities. Volume 11, No. 2, pp. 125-141.

Al-Tilimsani, A. A. M. U. (2009). Sharh Umm al-Barahin, Beirut: Dar al-Kutub al-'llmiyyah.

Al-Urmi, M. A. A.,(2015). Al-Kawkab al-Mashriq fi Sama' 'Ilm al-Manțiq 'ala al-Sullam alMunawraq. Mecca: Dar al-Minhaj.

Vaughn, D. W., Green, S., Kalayanarooj, S., Innis, B. L., Nimmannitya, S., Suntayakorn, \& Nisalak, A. (1997). Dengue in the Early Febrile Phase: Viremia and Antibody Responses. Journal of Infections Disease. No. 176, p.p 322-330. 